\title{
Community Opinion on Environmental Information System for Urban Rivers
}

\author{
Yonik Meilawati Yustiani, Latifah Mutmainah
}

\begin{abstract}
River water quality in urban areas needs to be maintained so that it can be used properly. Environmental information systems have become incompetent in developed countries and have produced good monitoring and maintained river water quality. This research was conducted to find out the views of the community on the needs of environmental information systems related to river water quality in urban areas. Data from the community was obtained by distributing questionnaires through internet media with the aim that respondents be reached from among those close to the habit of accessing information online. Based on data collection, it was found that the majority of the community stated that river water quality was important to optimize the function of the river. System information is believed to be very necessary in an effort to improve river conditions for government agencies, and is also considered important for the community. River data that is important to the community, not only the quality of the water but the information related to its use as a tourist area. Most people need information about urban river water quality. The results of this study recommend a river information system design that is complete with a variety of substance contents intended for people with different background needs and interests.
\end{abstract}

Keywords : community opinion, information system, urban rivers

\section{INTRODUCTION}

Rivers are ecosystems that are often found in urban areas and provide support for the city's environmental conditions. Therefore, guarding the quality of the river is a very important thing to do. Pollution and environmental degradation that occur in big cities in Indonesia results in rivers not being able to function optimally properly, even though rivers often have a multifunction other than as aquatic biota ecosystems. For example, the Cikapundung River in Bandung is used by the government and the community as raw water sources for drinking water, tourist attractions at some points, hydro power plants, etc.

Revised Manuscript Received on August 30, 2019.

* Correspondence Author

Yonik Meilawati Yustiani*, Department of Environmental Engineering, Universitas Pasundan, Bandung, Indonesia. Email: yonik@unpas.ac.id

Latifah Mutmainah, Department of Environmental Engineering, Universitas Pasundan, Bandung, Indonesia.. Email: 163050031.latifah@mail. unpas.ac.id

(c) The Authors. Published by Blue Eyes Intelligence Engineering and Sciences Publication (BEIESP). This is an open access article under the CC BY-NC-ND license (http://creativecommons.org/licenses/by-nc-nd/4.0/)
River water quality is important when paying attention to these functions, especially as raw water for drinking water and tourist attractions. The Indonesian government, through ministries and agencies that are associated with the environment, has made several efforts to restore river conditions in urban areas, including the quality of the water. In developed countries safeguarding river conditions is carried out in various ways, including online monitoring in an environmental information system. A real time system, attractive and informative display becomes a source of data for the public, private parties, and government. This data can be used to determine the point of tapping water for a specific purpose, to overcome pollution or detected damage, to get initial information about the tourism area, etc. The online information system that is currently popular among the public is the BPS (Central Bureau of Statistics) portal. The demographic data contained in the BPS portal is relatively complete and complete. The community easily accesses the BPS portal and retrieves the data needed without experiencing significant difficulties. Demographic data can be used for various purposes, especially for research or study. The environmental information system in Indonesia is still very little. Article $28 \mathrm{~F}$ of the 1945 Constitution states that everyone has the right to communicate and obtain information to develop their personal and social environment and has the right to seek, obtain, possess, store, process and convey information using all types of available channels, which this then it is emphasized in Law Number 32 of 2009 concerning Environmental Management article 62 paragraph (2) which requires both National and provincial or regency / city governments to disseminate environmental information to the public. (3) states that the environmental information system contains at least information about the status of the environment, hazard maps of the environment, and other environmental information [1]. To achieve this goal, the Ministry of Environment and Forestry (KLHK) through the Data and Information Center (PUSDATIN) has developed an Environmental Information System Portal (SILH) as an online media that will be used as a means of storing, processing, data flow, and publishing data and information at the address http://silh.menlh.go.id. SILH Portal is intended besides KLHK with each work unit, also can be utilized by regional environmental agencies. This SILH Portal, in which the website of each region is available with access as a user and has several applications that can be accessed online so as to provide convenience to the Regional Environment Agency (BLHD), 
the Center for Ecoregion Development (P3E) and KLHK in conducting exchanges data and information. For now, the application that is ready to use is the SLHD (District Environmental Condition Status) application. In the application, BLHD only needs to input SLHD data in accordance with the 2013 SLHD preparation guidelines that have been refined to become guidelines for the preparation of the 2014 SLHD.

The public still does not know about the information system available for these environmental data. The SILH portal provided by KLHK is currently inactive. This condition logically raises an estimate of the indication that environmental information systems are not needed by society at large. Therefore, this study specifically examines the community's views on environmental information systems related to river water quality. The results of this study can be used as recommendations for the formulation of information systems that are useful for the public, the private sector and the government.

\section{METHODOLOGY}

Data on people's views on the importance of environmental information systems related to river water quality was obtained through distributing questionnaires. Questions in the questionnaire were compiled using Google Form and distributed through social media, whatsapp and line conversation media. Respondents who were targeted were the general public who already knew the internet well. This was determined so that respondents who were netted were people who were accustomed to finding data on the internet.

There were 36 respondents who filled out the questionnaire through Google Form with the following questions:

- The importance of river quality conditions

- People's view of the current condition of urban rivers

- Community knowledge of river information systems

- Community needs for river water quality information

\section{RESULT AND DISCUSSION}

\section{A. The Importance of River Quality for the Community}

In general, the majority of the people through respondents stated that river quality is not important. In big cities, river water utilization, especially in terms of quality, is more widely used by government agencies. Various communities and governments began to care about the quality of river water in their area [2]. For example, the Bandung City Office of Environment and Hygiene has a routine of taking river water samples to be analyzed for each parameter, then the results and recommendations for the quality of river water are arranged. While people are more interested in river conditions that can be seen directly. Respondents who stated that river water must be maintained in quality include not only the people who live near the river but also those who live far from the river. The quality of polluted river water can affect public health both directly and indirectly, for example through wells of raw water sources located near rivers [3].

River water quality is something that must be maintained, especially if it has a lot of designation. For example, the Cikapundung River and the Citepus River in Bandung,
Indonesia, function as raw water sources for drinking water, irrigation, tourism, etc. [4], [5]. But on the other hand, this river is also a place for the disposal of domestic waste from housing that is mostly without processing first [6].

\section{B. Community Perceptions of the Vondition of Urban Rivers}

Respondents of this study stated that the condition of urban rivers suffered heavy pollution. This is assessed visually without laboratory testing. Water conditions in urban areas, including the city of Bandung, appear to be polluted from the content of garbage that pollutes the river and the color of blackish river water. Visually, people can only see the surface of the river. Based on data held by the Bandung City Environment and Hygiene Office and the West Java Province Environmental Agency, the quality of the rivers in Bandung and the Citarum River is heavily polluted, especially when compared with the quality standards for the allotment of drinking water and fisheries. The data can be obtained only if you visit the relevant office.

Figure 1 shows the opinions of respondents on the quality of river water that is around in the category of very good, good, bad and bad.

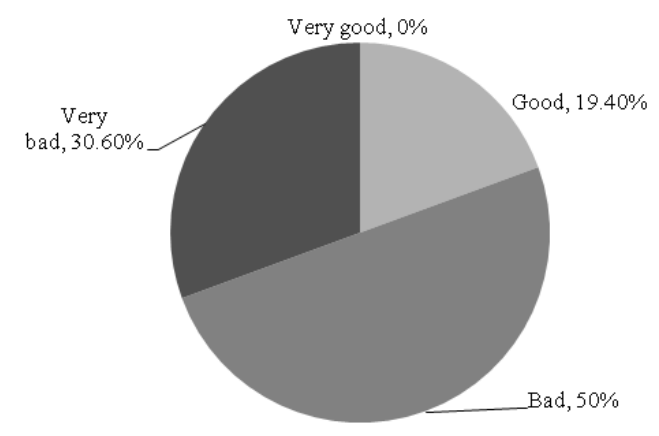

Fig. 1. Respondents' assessment of river water quality.

Respondents considered that there were no rivers around them that had very good quality. As much as 50\% of respondents stated that the quality of sungi water was in poor condition. Pollution that occurs in rivers in urban areas comes not only from domestic waste, but also from industrial waste, such as those that occur in the Citarik, Cimande and Cikijing Rivers in West Java Province [7]. Based on the latest survey, it was stated that out of 194 rivers in Indonesia, 73\% were contaminated with toxic waste [8].

\section{Availability of Information about the Current Water Quality}

Based on the questionnaire distributed, it was found that the public was not aware of any information regarding the quality of river water in an online system. There are respondents who need river water quality data, but only in the news section, and the data obtained is not quantitative parameter data with its concentration.

Published By: 
Figure 2 shows the results of a questionnaire distributed to respondents regarding the availability of information about the current quality of river water.

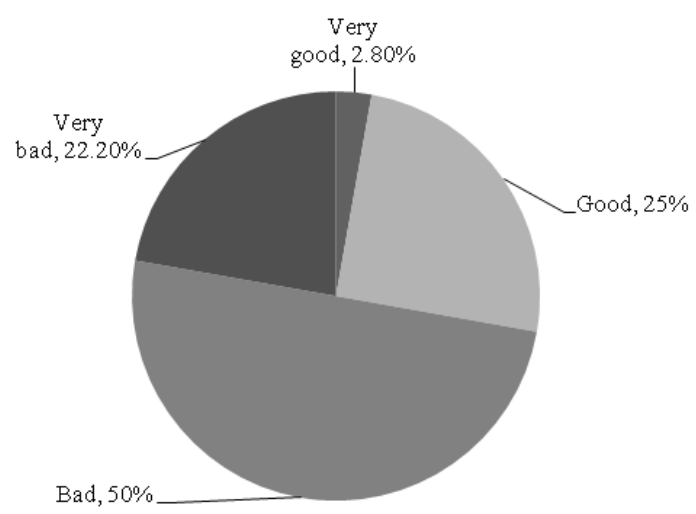

Fig. 2. Community opinion on the availability of information about river water quality.

As much as $50 \%$ of respondents stated that the availability of information about river water quality is currently poor. The constraints faced by the information giver include the sensitivity of the data to the stability of the condition of the community so that the publication of data requires a screening process first [2].

\section{Community Needs for River Water Quality Information}

All respondents stated that they needed information about river water quality. This data is useful for the community to determine whether the river water can be used or not as needed. Efforts to monitor river water quality periodically and online need to be continuously carried out and government efforts with the community, whether law enforcement or socialization to improve the quality of the aquatic environment, need to be continued [9]. For government officials, it requires river water quality data for several purposes, including determining decisions and policies, verifying river water phenomena, predicting river water quality, compiling analyzes of environmental impacts, and determining the designation of a water body [2]

The wishes of the community regarding river water quality information systems include actual, easy and fast data if needed. In addition, complete data covering various aspects such as physical, chemical and biological parameters is also expected by respondents in the information displayed. The most desirable data delivery by the community is through online and digital internet that is easily accessible at no cost. For the general public, information about the results of a more complete analysis also needs to be included, including interpretation of data whether the river water is safe or not, can be used for drinking water or other purposes, etc. This information can be useful to improve the level of public awareness of efforts to maintain the river environment [10].

\section{E. Community Needs for River Water Quality Information}

Several studies have been carried out in an effort to build an information system for river water quality in Indonesia. The river monitoring system can be made in accordance with the conditions of the watershed in Indonesia and can support the management function of natural resources (water resources). Water quality monitoring devices can be supported by several sensors, data loggers and data communication modules. Based on several experiments, it is proven that monitoring river water conditions can be done remotely (remotely) by utilizing telemetry technology [11].

The monitoring system that can be directly published online is the $\mathrm{pH}$ and temperature values due to the availability of sensors. The sensor for each node is connected to Arduino as a processing unit, the data read from the sensor is sent to the sink node via the wireless device. The sink node uses a PC that also functions as a database server and web server. The results of the test can be displayed via the webpage that has been built [12].

Availability of information on this river's water quality can directly or indirectly improve the condition of the aquatic environment. Respondents in this study stated among other things that by knowing the quality of river water, it can provide information about the condition of the river in the upstream area so that it can anticipate and / or overcome the possibility of a factory that is not in accordance with or comply with the EIA document. In addition, with this information, it is expected that the community will be educated so that they can increase efforts to control river water quality. It is also hoped that if the community finds out that the surrounding river is not good enough, it will grow reluctant to pollute the river.

\section{CONCLUSION}

This study shows some results, i.e.:

- The majority of the community believes that river water quality is important, especially so that it can be used as a basis for optimizing river functions.

- At present the community states that river water quality in Indonesia is in poor condition.

- Information about river quality is needed by the community but currently it is not yet available properly, even though it is very necessary to improve the condition of the river.

- Studies on river water quality information systems have been carried out and can be recommended for implementation.

\section{REFERENCES}

1. http://ppebalinusra.menlh.go.id/sistem-informasi-lingkungan.htm (accessed May 2019)

2. Y.M. Yustiani, L. Lidya, T. Matsumoto, I. Rachman, and I. Komariah, "Formulation of the Integrated Information System of River Water Quality in the Cikapundung River, Bandung, Indonesia," International Journal of Engineering and Technology, vol. 9, no. 1, pp.137-142, Feb-Mar 2017. DOI: 10.21817/ijet/2017/v9i1/170901416

3. H. Pradiko, Y.M. Yustiani, and Santika, "Kajian Beban Pencemaran Limbah Cair dengan Parameter BOD dan DO dari Daerah Permukiman di Sungai Citepus, " Journal of Community Based Environmental Engineering and Management, vol. 2, no.2, pp.69-76, September 2018. DOI: 10.23969/jcbeem.v2i2.1459

4. Y.M. Yustiani and L. Lidya, "Towards an Information System of Modeling and Monitoring of Cikapundung River, Bandung, Indonesia," Procedia Engineering, 154, pp. 353-360, 2016. DOI: 10.1016/j.proeng.2016.07.490

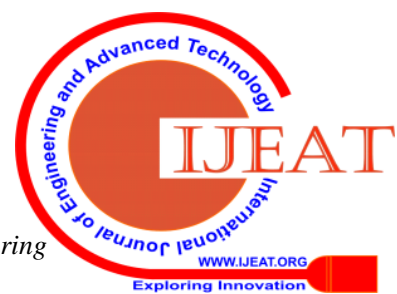


5. Y.M. Yustiani, L. Mulyatna, and F. Pranata, "The Deoxygenation Rate Determination Based on Physical Condition of River Body, Case Study of Citepus River,” AIP Conf. Proc., 1554, pp. 281-284, 2013. DOI: 10.1063/1.0340

6. Y.M. Yustiani, A.W. Hasbiah, T. Matsumoto, and I. Rachman, "Identification of important efforts in urban river water quality management (case study of Cikapundung River, Bandung, Indonesia)," IOP Conf. Series: Earth and Environmental Science, 245, 2019. DOI:10.1088/1755-1315/245/1/012033

7. R. Fadhilah, K. Oginawati, and N.A.Y. Romantis, "The Profile of Citarik, Cimande and Cikijing Rivers in Rancaekek District, West Java, Indonesia," Indonesian Journal of Urban and Environmental Technology, vol. 2, no. 1, pp. 14-26, 2018. DOI: 10.25105/urbanenvirotech.v2i1.3553

8. https://mediaindonesia.com/read/detail/186560-kualitas-air-sungai-73buruk, accessed June 2019.

9. S. Yudo and N.I. Said, "Status Kualitas Air Sungai Ciliwung di Wilayah DKI Jakarta," Jurnal Teknologi Lingkungan, vol. 19, no.1, pp. 13-22, 2018.

10. H.S.D. Kospa, "Kajian Persepsi dan Perilaku Masyarakat terhadap Air Sungai," Jurnal Tekno Global, vol. 7, no.1, pp. 21-27, 2018.

\section{AUTHORS PROFILE}

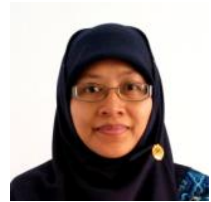

Yonik Meilawati Yustiani received the Bachelor and Master degree of Environmental Engineer in the Department of Environmental Engineering of Institut Teknologi Bandung, Indonesia. The doctoral degree was received from the Tohoku University, Japan with full scholarship from the Ministry of Education of Japan. She is currently working as a faculty member in the Department of Environmental Engineering in Universitas Pasundan. Her research interests are environmental quality management, modeling of coastal and river pollutants distribution, young generation environmental awareness, environmental education, monitoring tools innovation, etc. She received several research grants from the Ministry of Research, Technology and Higher Education during period of 2011-2018.

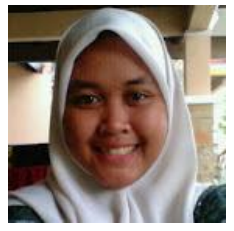

Latifah Mutmainah is in her third year enrolling undergraduate course in the Department of Environmental Engineering of Universitas Pasundan. Her research interest is young generation trend on environmental issues. 